\title{
Mirror or Masquerade? On Representational Ethics in Cultural Heritage Museology And Tourism
}

\author{
Râna Campbell ${ }^{1}$ \\ ${ }^{1}$ Master's Program in Coastal and Marine Management, Faculty of Business and Science, University \\ Center of the Westfjords, University of Akureyri, 400 Ísafjörður, Iceland
}

\begin{abstract}
Icelandic cultural heritage museology is embedded in a complex of social, political, and economic matters, at both the national and continental levels, that look to tourism as an opportunity for development in rural regions. The present paper draws on master's research that examined the relationships of Westfjords communities with two maritime heritage museums in the region. Two qualitative case studies based on in-depth, semi-structured interviews with heritage producers connected to each site were supplemented with additional qualitative data from a focus group comprised of five Westfjords residents. Open and closed coding schemes based on the condensation of transcripts into thematic units were used to analyze the data, thus producing descriptions of the representational ethos of each museum, and findings were subjected to ethical analysis. Both museums were found to reflect contemporary issues that are subject to debates about cultural identity, heritage, and representational style and ideology, while analysis revealed that there is a persistent danger of oversimplifying or distorting cultural representations, particularly where each museum has stakes in tourism. This was judged a potential disservice to the nuanced identities of local communities, and a recommendation was put forth for museums to engage conscientiously with questions of identity and cultural representation.
\end{abstract}

\section{Introduction}

It is a well-documented fact that tourism is one of the most widespread and fastest-growing industries in the world [1-7] and that, in the vast majority of countries visited, there is an ongoing, steady rise in the annual number of visitors [8]. Many countries have embraced the potential for economic growth afforded by the foreign tourism market $[3,9-10]$ and have been keen in developing various arrays of domestic products and services to meet the demands of the industry [3,9].

The increased specialization of tourism products and services in response to perceived consumer demand has led to the appearance of numerous niche markets [4, 9-12], each of which purports to deliver a unique experience distinct from the generic products of mass holiday tourism $[13,14]$. While there would appear to be some disagreement as to whether or not cultural heritage tourism is a niche in and of itself $[4,14]$, it is nonetheless an important sector of the industry that appeals broadly to travellers interested in learning about "culture, heritage, and ethnicity" [4,15], whether their own or another's [4]. 
From political and economic perspectives, many countries, whether developing, home to rural populations confronted with the various challenges of modernization and globalization, or emerging from difficult and transformative histories, see cultural heritage as an important resource for the instauration of a thriving tourism business $[5,10,15-16]$. Cultural heritage tourism, in turn, is perceived as a means of maintaining traditions by putting them to new uses, thus reinforcing culture among natives and promoting it among foreign visitors [5, 10, 16-18]. This has been the case in Europe, where a "politics of heritage" [5] that encourages the strengthening of community bonds through uptake of common cultural identity [5, 16-17], coupled with the promotion of a "cultural economy" [16] that looks to tourism as a vital resource for regeneration and growth, has become the dominant paradigm for regional policy [19].

The state of cultural heritage tourism in Iceland is in many ways reflective of the European and international political climates. Neo-liberal policies that have shaped the economy over the past twenty-five years have made their way into a regional development policy both heavily invested in tourism and cognizant of culture as an asset to the industry [16]. A conspicuous legacy of these policies has been the ongoing appearance of new, privately owned cultural heritage museums and exhibition centers throughout the Icelandic countryside [17, 20].

Debates within the academic community as to the authenticity and value of these institutions are common, with critics either finding fault with their heritage content or their methods of planning and dissemination. In the first case, as many such museums are devoted to supernatural elements of intangible heritage, such as folk tales and pagan practices, they are criticized for valorizing traditions that some associate with past ignorance [17] and prefer to exclude from concepts of Icelandic identity. In the second case, it is believed that many of these institutions, in a hurry to begin operating to the end of capitalizing on tourism, lack both serious research and the contribution of scholars possessing knowledge in the appropriate fields, and are thus perceived as "vulgar" cultural representations [A. H. Pálsdóttir, personal communication, March 2014].

Much of this criticism is connected to their representational styles, which focus on design and in many cases employ multimedia arts and technologies in order to create a space for visitor experience. Such innovation is thought to be motivated by a desire for appeal as a tourist attraction, however, the few scholars currently addressing it see it as brigning timely and interesting changes to historiographic [21-22] and ethnographic [17] museology in Iceland. On one hand, innovative design has made history more interesting and more accessible to a broader public by providing lively, sensory exhibits with greater emotional appeal, by contrast with the static, text-and-collection-based style of more traditional exhibits, which require a higher degree of intellectual commitment from the audience [2122].

On the other, in representing the immaterial, the imaginary, and the supernatural, some of the newer museums are said to have opened access to numerous facets of Icelandic heritage which, though undervalued or even shunned by contemporary standards, nonetheless belong to the cultureand, along with this, to have raised the profile of intangible heritage as well as of typically underrepresented social and demographic groups [17]. In both cases, the representational ethos of the new museology departs from elite historical narratives [23, 24, 25, 26] and high culture policies [17], and reinstates the vernacular in the cultural cannon [25]. Thus, concepts of cultural identity that diverge from the 'authorized heritage discourse' [27] are revalorized, and cultural representation, as a consequence, is democratized. It is in this sense that representation might be viewed as a finely-tuned fixture of style and ideology.

Nonetheless, identity is not only a phenomenon that plays out across multiple spatial scales [28], but is plural, fluid, mutable, and discursive [27-29]. Thus its connection to culture, its conceptualization in heritage selection, and its subsequent embodied representation is the greatest challenge facing cultural heritage museums. This has consequences for cultural tourism, as well, especially in the Icelandic context, given that the new ethnographic museums are largely the products of an economic policy with the tourism industry at its heart. 
To the extent that museums present images of a culture to foreign visitors, they may be said to participate in a branding of sorts [5]. These images often find their way into cultural tourism marketing or destination branding campaigns and, unless they have been deliberated upon with care from the outset, they risk being more representative of one or a few dominant discourses in a society rather than of a culture the society identifies with, per se [30], or, in a worst case, of alienating certain groups and individuals.

This paper will re-visit two qualitative case studies from my master's research that investigate one relatively new museum and one older, more traditional one in Iceland's most remote region, the Westfjords. The purpose of these case studies was to glean an understanding of the concepts of identity at the heart of each museum and to examine the ways in which these are translated into cultural representations, with the final objective of analyzing these translations from an ethical perspective.

Selected findings will be presented in light of these matters and checked against the findings from a focus group that was held to garner the opinions of Westfjords residents regarding cultural heritage, identity, and the roles and responsibilities of heritage museums. In closing, the discussion of these findings will be related to broader topics of ethical relevance in rural cultural heritage tourism.

\section{Methodology}

\subsection{Tangible and Intangible Heritage in the Westfjords of Iceland: Two Case Studies}

The Westfjords came to be permanently settled as a result of developments in the fishing industry, and this history is upheld as fundamental to the cultural identity of communities in the region [31-34]. Thus, it is befitting, when undertaking to examine concepts of cultural identity in the region, to investigate its maritime heritage. As part of my master's thesis research, I selected the Westfjords Heritage Museum (WHM) in Ísafjörður, northern Westfjords, and the Sea Monster Museum (SMM) in Bíldudalur, southern Westfjords, as exemplars of the region's tangible and intangible maritime heritage, respectively, for case study.

The former is a seventy-three-year-old, publicly-funded museum built on the site of an old trade and service station to the local fishery (operative between the late eighteenth and early twentieth centuries). The latter is a five-year-old establishment paying homage to the area's popular sea monster folklore, the product of a private business initiative.

These case studies were built on two sets of semi-structured, in-depth phenomenological interviews with heritage producers of varying capacity, i.e., curatorial, consultative, financial, etc. Five of these were conducted in relation to the SMM and seven in relation to the WHM. Interviews focused, on one hand, on the people and communities surrounding each site, exploring the ways in which they experience and engage with maritime heritage and with culture, more broadly.

On the other, they focused on the museums themselves, taking into account questions of their purpose, identity, and value. Thus, the study examined each museum's dual function as a cultural resource for the local community and a site of interest for tourists, as expressed via the experiences of the informants.

\subsection{Focus Group Discussion: Local Perceptions of Heritage, Identity, and Representation}

As the case studies focused on information collected from interviews with people generally connected to the operations of the SMM and the WHM, a focus group discussion among local residents having no such connection was conducted as a secondary method for gathering data. The purpose of this was to gain an understanding of their conceptions of cultural heritage, the roles and 
responsibilities of cultural heritage institutions, and their perceptions of the SMM and WHM as cultural heritage institutions, and through this to cast light on the data collected from interviews.

Further, the intent was to level out the age, gender, and ethnicity biases inherent in what had proven to be a demographically homogeneous interview sample. Likewise, the questions for discussion were conceived to address issues that had not arisen in the course of interviewing, such as the experiences of minority groups of Westfjords maritime heritage, as well as the representation of these groups, or lack thereof, particularly by the WHM.

\subsection{Thematic Coding of Data}

A two-tiered open coding scheme [35] was used for interview data analysis. One set of generalized, descriptive codes, derived from the condensation of informants' narratives into thematic units [35] was created in the margins of each transcript. A second, more interpretive set indicating the subtler themes present throughout the narratives was produced by means of a simple colour-coding scheme.

In order to explore the internal relationships among the codes at each level as well as their crosslevel relationships, the codes were organized into hierarchies and grouped as such. A manual technique was then used for arranging the groups into various physical positions in relation to one another, which brought forth patterns and divergences among them. This process generated overarching analytical categories which, in turn, made it possible to formulate broad statements describing the ethos of each museum.

By contrast, because the focus group was conceived as a supplement to the interviews, the data it generated were analyzed using a "concept-driven" coding scheme [35, p. 44], whereby a set of $a$ priori theoretical categories, based on information and issues generated by the interviews, was used to guide the condensation of the focus group transcript into thematic units. With the help of these units, the original theoretical categories were associated with specific segments of text, to be described, at the time of writing, in relation to the ways in which they were manifest in the discussion.

\section{Findings}

\subsection{Sea Monster Museum}

The SMM's value as a cultural institution lies at the crux of its ability to create a space for enacting and engaging with local identity/ies and its experiential media for doing so. There is significant evidence of a distinct sense of local identity in Bíldudalur, centered on a talent and propensity for storytelling which, in turn, accounts for the vibrancy of the area's sea monster folklore. Further, it is believed that this identity has been reawakened and revitalized with the construction and opening of the museum. Local attitudes about the existence and nature of sea monster themselves, are, however, very complex, and the subject of sightings is said to be taboo.

More subtly, individual identities embed themselves in the local cultural landscape, and find expression through a sense of rootedness in it. Thus each individual interviewed has a singularly unique vision and aspires to something distinct and personal in his efforts lent to the SMM, yet a sense of solidarity with the community unites most in a creative process that aims to benefit the village both economically and culturally.

There is also, however, some evidence of dissent or disapproval from individuals within the community who do not believe in sea monsters and may perceive the SMM as an establishment that promotes falsities about the locals or even about Icelanders at large. There is insufficient data to draw any conclusions about the positions and reasoning of these individuals. 
Informants often refer to the broader Icelandic and international settings for sea and lake monster lore, cite praises of the museum from foreign visitors, and use examples of internationally renowned museums by way of comparison and contrast. It might be said, then, that the SMM serves to assert an identity for the local community at larger spatial scales, and thus is thought of by informants as representative of a culture that both defines the community and places it on the map, so to speak. It is, however, primarily tourist- oriented in its operations, as the exhibit has not changed since the museum first opened to the public in 2009 and its novelty has thus worn off for locals.

Maritime heritage is an elusive concept in this case study. Sea monsters themselves are generally not thought of as heritage and the sea monster folklore is not thought of specifically as maritime heritage. Rather, it is thought of as oral and literary tradition, in the same class as stories about elves (álfur), hidden people (huldufólk), and ghosts (draugar). However, in most cases there is a clear connection between the maritime culture of the fishing village and the identities of those who grew up there. This is at times punctuated by identification with the nation's fishing history, but for the most part it is expressed as childhood memories, family, feelings, experiences of place and life events, all of which sea monster folklore, to varying degrees, plays a part in. In this sense, each informant sees a great deal of value in not only the preservation of the folklore, but its embodiment in a creative exhibit that makes use of multimedia arts and technology to create an atmosphere that brings the stories to life. Some also see scientific value in the SMM's potential to function as a platform for the production and exchange of scientific knowledge about sea monsters, a topic that can only receive superficial treatment given the scope of this paper.

While the main driver for investing effort in the museum is a desire to restore livelihood in the village, the ideal medium for achieving this is lived experience. It is thought that by being able to provide guests with an experience that defies traditional museology, the SMM will succeed both economically and culturally, having delivered a high quality product that revalorizes local heritage.

\subsection{Westfjords Heritage Museum}

By contrast with the SMM, the WHM has been struggling to balance its traditional role as a site of heritage preservation serving local communities with pressure from the tourism industry to serve as a hybrid of entertainment and education for foreign visitors. Additionally, informants present a case of diffuse geographic identity and more widely varied life experiences than do SMM informants. Because of this, the WHM itself is subject to equally diffuse opinions, appraisals, and direction. Nonetheless, despite its perceived potential to generate revenue for the community through tourism, informants' valuation of the WHM is predominantly cultural.

Cultural identity is, in fact, the centerpiece of this case study, and is typified by identification with the nation's history and the assertion of a national character. The dominant view is that identity is defined by history - that the history of the nation is not only the story of where Icelanders come from, but an explanation of who they presently are. The same is true of local and regional histories, although expressed to a lesser degree. Cultural identity and history are treated as two sides of the same coin in discussions of heritage. Consequently, there is a perceived need for an institution that houses this history and gives form to cultural identity as expressed through the national character.

Cultural identity, as moulded by the nation's maritime history, is a complex of immaterial ways of relating to the material world. Because the WHM's exhibits display authentic material artefacts from various eras in Icelandic and Westfjords fisheries, they are generally thought of as highly representative of regional and national identities, even so far as to capture and communicate something of the immaterial aspect of informants' relationships to history and felt experiences of the sea. The challenge to those responsible for operating the WHM is to make managerial and curatorial decisions that will allow for increasingly experiential exhibits, thus answering to perceived changes in the way that society views and interacts with museums, without demeaning the heritage or subtracting from the WHM's educational function. 
This is seen as a crucial endeavour in order to restore local interest in the museum and in the heritage it represents, and the challenge is even greater when one takes into account the need, felt by some informants, to add a degree of theme-park flair to the museum in order to successfully attract tourist currency. While the potential for distortions in cultural representation resulting from this is obvious, the absences or subdued representation of some groups, particularly of women and ethnic minorities, both of whom have been instrumental in the growth and survival of Westfjords fisheries, is less so. The existing data suffices primarily in showing that although attitudes towards these groups are positive, they are not at the forefront of informants' thinking about cultural heritage representations or museology.

\subsection{Focus Group}

The focus group provides a snapshot of social perspectives on heritage and serves as a platform for critical analysis of the SMM and WHM from the vantage points of social, political, and economic issues. Most importantly, a general discussion of the meaning of cultural heritage, identity, and representation yields the notion that cultural identity is a historical phenomenon characterized by the social dynamics of a place and by self-differentiation from other cultures. Further, cultural heritage museums have a dual role wherein they must at once be attentive to the local community and to tourists.

Regarding the former, heritage preservation and cultural education are key responsibilities, whereas regarding the latter, business acumen and authentic cultural representation figure prominently. Maritime heritage is seen as the core of cultural identity in the Westfjords and thus it is thought crucial for it to be represented in any regional heritage museum. However, it is also seen as but one among several facets of the region's cultural landscape that merits representation. In this sense, the WHM, although perceived as an important cultural institution for the community, is seen as somewhat narrow in its scope.

It is likewise thought that given adequate funding, the museum could do better in providing interesting experiences of Westfjords heritage. Further, participants unanimously agree that the foreigners currently comprising the greater proportion of the workforce in regional fish factories, who have been immigrating to the Westfjords for approximately thirty years to fill positions that are decreasing in popularity among Icelanders, are entitled to inclusion in conceptions of regional and Icelandic heritage and, consequently, representation by the WHM.

There is little mention, however, of the place of women in the region's heritage, except by one female participant of foreign origin. She identifies with the hard work and independence of the coastal women who historically processed the landed fish, and is appreciative of the fundamental role they had in structuring the family and society as Westfjords fishing villages came to be settled permanently. Nonetheless, neither she nor any of the other participants comments on the seemingly unequal representation of women by the WHM.

Although there are varying degrees of divergence in opinion as to what constitutes heritage, whom it belongs to, and how it should be represented qua heritage, all agree on the business opportunities inherent in it qua tourist interest. It is clear, however, that they see the role of heritage museums as being split between the two distinct functions of operating as businesses or as institutions for cultural preservation and education. While, in general, the concept of heritage as a product for consumption is not frowned upon, there is some concern about the risk it runs of becoming a production, i.e., a staged, inauthentic claim to representation closer to "showbusiness" in its demeanour.

In this vein, all participants but one (none of whom is from Bíldudalur) are highly critical of the SMM, which they perceive as a crass, commercial tourist attraction that grossly misrepresents Icelandic people and their culture by blurring the line between the sea monster folklore and a supposed belief in the existence of sea monsters. According to them, while the folklore is admissible to heritage, the very existence of such an institution, which markets itself as a heritage museum, is vulgar. 
This view echoes those of some Icelandic scholars engaged in debates surrounding the emergence of these kinds of museums/ tourist attractions and the 'new ethnography' [17] they participate in. Yet, even the participants most virulently opposed to the SMM concede that it is a fine business opportunity grounded in a novel marketing strategy. One admits that he would encourage tourists to visit and even go so far as to play along with the idea that there are sea monsters dwelling in the fjord in which it is situated (Arnarfjörður), in the interest of keeping tourist currency circulating in the region.

\section{Discussion}

It is interesting that while broad discussions of maritime heritage bring about cross-scale expressions of identity in both case studies, discussions relating more strictly to the ideals and operations of each museum show that the SMM and the WHM deviate from one another where considerations of identity are concerned, such that the SMM associates itself more closely with local identity and the WHM with national identity. This deviation entails a separate set of problems for each museum.

The individuals regularly involved in planning and operating the SMM are united by a social ideal, i.e., to do something of value for the local community, yet it must be asked whether their perceptions of local identity and therefore their visions for the museum might not be overly influenced by what they, as individuals, identify with most in the local cultural landscape. For example, those who insist on characterizing locals as storytellers should be wary of doing so merely on the basis of the abundance of reported sightings in the area, which may or may not be of the realm of yarns or folk tales.

Similarly, because some informants have indicated that there are dissenters within the local community, the museum must be careful not to lay claims to representing the beliefs or interests of the entire village. One might conjecture that such a gesture, concretized over time, would contribute to discord in the community between those who identify with the folklore and those who do not, or even between 'believers' and 'non-believers' in the existence of sea monsters. Similarly, it may serve to marginalize and fuel contempt for 'believers', who are thought by some to be a minority, by formalizing stereotypes in their images and narratives as exhibited by the SMM [36].

This raises questions about the status of intangible heritage as opposed to tangible heritage in the Westfjords and perhaps throughout Iceland. The contempt shown for the SMM by focus groups participants, along with the fact that the museum has encountered resistance within its own community, indicates that there is a degree to which tangible heritage may enjoy greater credibility in society and be more valuable to the cultural mindset, in general - an idea that is likewise suggested by the literature [17].

Although the SMM is focused on offering an experience and is thought of as a clever and creative endeavour from a business perspective, the WHM makes more vocal claims to authentic cultural representation by virtue of its exhibition of historically significant artefacts, and is likewise perceived by many as a more important cultural heritage institution. Cultural representation, then, is for the WHM rooted in material authenticity, and it would seem that the materiality of tangible heritage has a greater bearing on individuals' feelings of cultural identity.

But what of existential authenticity? A concept derived from the work of $20^{\text {th }}$ century existentialist philosophers and the closest thing to a theory of ethics belonging to this school, existential authenticity is neither mentioned nor alluded to by a single informant and yet instances of it abound throughout the data, particularly where intangible heritage is concerned. The SMM, for example, by being the point of convergence of numerous individual identities, each working towards a unique vision for the packaging and presentation of sea monster folklore and pseudoscience, is, effectively, a platform for enacting one's interests and values and, as such, fully taking up the task of one's existence. 
Similarly, by striving to offer an authentic affective experience derived from sensory, emotional, and intellectual engagement with its subject matter, the SMM is indeed inviting visitors to step outside the conventions of their daily lives [37] and to embrace their own existences through participation in the local culture. In this sense, it might be said that the SMM is breaking the barriers of traditional representational styles built on the imposition of a self/ other dynamic. The question as to whether it is in some way misrepresenting local or Icelandic culture must, then, be re-evaluated within this framework.

The WHM belongs to the category of older heritage museums in Iceland that, as Bernharðsson [21, $22]$ indicates, employs a more stagnant and less affective style of representation, appealing primarily to the intellect and making use of text-heavy informative plaques, thereby potentially alienating some visitors by distancing them from the heritage it is intended to represent. Yet, informants to the WHM case study give every indication of being aware of evolutions in museology as well as of wanting to innovate their own representational styles.

In its gradual orientation toward offering dynamic experiences rather than static exhibits for passive viewing, the WHM is likewise seeking to engage with an altogether different kind of authenticity. It is interesting that such an ideal, which the WHM is being driven to adopt largely by virtue of catering to the tourism industry, is the same one that is perceived by some as the only viable way of reconnecting the local community and Icelanders, in particular the youth, to the heritage it represents. Nonetheless, the idea of promoting and engaging in existential authenticity, which by turns may be viewed as suspending disbelief, 'letting go', learning, experiencing, 'being oneself', and having fun, must certainly not be perverted such that it encourages an 'anything goes' mentality in the structuring of museum displays and experiences, particularly where either museum (or any other, for that matter) turns its attention to economic and business concerns.

Representation, as it were, is for both museums a meeting of style and ideology, and thus the matter of just and ethical representation is indeed a fine line to tread. Although the individuals interviewed in the context of each case study can be situated within a similar cultural landscape due to common experiences of maritime culture, they differ widely in their ways of engaging with this landscape.

Thus, so do their outlooks on its interpretation and representation by museums. The SMM is clearly a participant in the 'new ethnography' [17] of the Icelandic countryside. As such, its focus on process and design $[21,22]$ signals concerns that Hafsteinsson \& Árnadóttir (2013) place at the heart of all such museums that are, as the products of regional development policy and an emergent cultural economy [16], preoccupied with the welfare of their local communities and the enjoyment of visitors. By contrast, the WHM's investment in its collection and traditional style of exhibition are testament to its concern for heritage preservation, while its plans to introduce more dynamic modes of representation over time signal the desire to reach out to local communities and Icelanders on the principle of the importance of heritage for society, as well as to attract and maintain the interest of tourists for economic purposes.

Most importantly from an ethical standpoint, however, is the notion that representative style and design feed back into identity either by maintaining or challenging the 'authorized heritage discourse' [27] that has given rise to the familiar imagery associated with Icelandic maritime history. The SMM, spurred on by business interests, has been quicker to enact this challenge by paying homage to folk culture and providing a space in which the public may actively engage with it through various media. Thus, it is the antithesis to museums such as the WHM that privilege a specific narrative of Icelandic history and representation of Icelandic culture, e.g., the story of the fisheries and the image of the fisherman.

Likewise, the SMM's attention to local identity is a unique counterpoise to the WHM's promotion of a supposed national character [28] which appears to exclude women and ethnic minorities, however unintentionally. By running the risk of romanticizing the past through the veneration of this character and the historical imagery it privileges, the WHM also runs the risk of generating stereotypes and fostering uncritical attitudes about it $[23,36]$. 
Thus, where the WHM has a duty to democratize its concepts of heritage and identity, the SMM has a similar duty to ensure that it not be caught in the trap of cultivating a single image of local identity to the exclusion of others. Similarly, because the SMM is of a markedly local flavour, it must be attentive to any possibilities of excluding the values of Icelanders from other localities and regions in its representations, a danger signalled by both Júlíusdóttir (2010) and focus group participants in different contexts. At present, this does not appear to be an outstanding threat, as all those involved with the museum are keen on expanding its scope to make it a national and international center for sea monster folklore and pseudoscience. However, given the complexity of beliefs about the existence of sea monsters and of the social attitudes regarding these beliefs throughout Arnarfjörour and beyond, it is no small task for the SMM to uphold a respectable standard of integrity in cultural representation.

In summary, the WHM must turn its own gaze and that of visitors to those currently excluded from its representations, whereas the SMM must remain attentive to the ways in which it acts upon local culture and contributes to the morphology of the cultural landscape. Thus, it is the duty of those involved in making decisions for the two museums, as spokespersons for culture, to engage with the depth and complexity of identity when crafting stories about people and places for release into the public sphere, asking themselves continually not 'what should we do?' but, rather, 'who are we, really, and what are we saying about ourselves?' Such critical gestures are at the basis of equitable practices in cultural heritage museology and tourism.

\section{References}

1. World Tourism Organization UNWTO. (n.d.). Why Tourism? | World Tourism Organization UNWTO. Retrieved July 21, 2014, from http://www2.unwto.org/content/why-tourism

2. H. Hassan, The Representation of Malaysian Cultures in Tourism Brochures, Procedia Soc. Behav. Sci., 118, 140- 151. doi: 10.1016/j.sbspro.2014.02.019 (2014)

3. S. Atan \& Y. Arslanturk, Tourism and Economic Growth Nexus: An Input Output Analysis in Turkey, Procedia Soc. Behav. Sci., 62, 952- 956. doi: 10.1016/j.sbspro.2012.09.162 ( 2012)

4. D.J.Timothy \& S.W.Boyd. Heritage Tourism. Harlow, Essex: Pearson Education Limited (2003)

5. S. Harrison, Culture, Tourism, and Local Community: The Heritage Identity of the Isle of Man, JBM, 94 (2001), 355-371. Retrieved from http://www.palgravejournals.com/bm/journal/v9/n4/pdf/2540083a.pdf.

6. M. Miller, \& J. Auyong. Coastal Zone Tourism: A Potent Force Affecting Environment and Society, MAR POLICY, 15 2,75- 99 (1991)

7. J. Morse, Tourism: Australia's Fastest Growing Industry, TOURISM MANAGE., 10, 3, 225228. doi: 10.1016/0261-5177(89)90079-4(1989)

8. The World Bank. (n.d.). International tourism, number of arrivals | Data | Table. Retrieved July 22, 2014, from http://data.worldbank.org/indicator/ST.INT.ARVL

9. D. Tassiopoulos \& N. Haydam, Golf Tourists in South Africa: A Demand-Side Study of a Niche Market in Sports Tourism. TOURISM MANAGE., 29, 5, 870-882V (2008)

10. J. Briedenhann \& E. Wickens, Tourism Routes as a Tool for Economic Development in Rural Areas-Vibrant Hope or Impossible Dream? TOURISM MANAGE., 25 (2004), 71- 79. doi: doi:10.1016/S0261-5177(03)00063-3 (2004)

11. M. Mostafanezhad, Volunteer Tourism and the Popular Humanitarian Gaze. Geoforum, 54, 111118. doi: 10.1016/j.geoforum.2014.04.004 (2014)

12. S. Cheng, J. Hu, D. Fox, \& Y. Zhang, Tea Tourism Development in Xinyang, China: Stakeholders' View. Tourism Management Perspectives, 2-3, 28- 34 . doi: 10.1016/j.tmp.2011.12.001 (2012) 
13. Macleod, D. (2006). [Book Review]. Niche Tourism: Contemporary Issues, Trends, and Cases, M. Novelli (Ed.). Elsevier, Oxford (2004), (27.95 pounds, 264 pp., xxi (pbk)), ISBN: 0-750-66133-X. Tourism Management, 27(6), 1426- 1427. doi: 10.1016/j.tourman.2005.10.020 (2006)

14. M. Robinson \& M. Novelli . Niche tourism: An Introduction. In Niche tourism: Contemporary Issues, Trends and Cases, pp. 1-11. doi: 10.1016/B978-0-7506-6133-1.50007-X (2005)

15. R. MacDonald \& L. Jolliffe, Cultural Rural Tourism: Evidence from Canada. Ann. Tour. Res., 30 2 (2003), 307- 322. doi: 10.1016/S0160-7383(02)00061-0 (2003)

16. M. Júlíusdóttir, M. (2010). People, Place and Culture in Regional Policy. Rannsóknir í $\begin{array}{llllll}\text { félagsvísindum } & \mathbf{X I}, & 67, & 67- & 77 . & \text { Retrieved }\end{array}$ http://skemman.is/is/stream/get/1946/6812/18508/1/6777_MagnfridurJuliusd\%C3\%B3ttir_STJbo k.pdf

17. S.B. Hafsteinsson \& H.B. Árnadóttir. Etnógrafísk endurnýjun íslenskra safna. Árbók Hins íslenzka fornleifafélags 2012, pp. 91- 112 (2013)

18. B.W. Porter . Heritage Tourism: Conflicting Identities in the Modern World. In B. Graham \& P. Howard (Eds.), The Ashgate Research Companion to Heritage and Identity (pp. 267- 281). Hampshire: Ashgate (2008)

19. European commission. (2013, June 10). Enterprise and Industry. Retrieved August 24, 2014, from ec.europa.eu/enterprise/sectors/tourism/background/index_en.htm

20. S.B. Hafsteinsson (2010). Museum Politics and Turf-house Heritage. Rannsóknir í $\begin{array}{llllll}\text { félagsvísindum } \quad \text { XI, } & 67, & 267- & 274 . & \text { Retrieved from }\end{array}$ https://www.academia.edu/430449/Museum_Politics_and_Turf-house_Heritage

21. Bernharðsson, E.P. (2007). Sagan til sýnis: ólíkar miðlunarleiðir. Birtist í Priðja íslenska sögupingið 18-21. maí 2006 : s. 97-102

22. Bernharðsson, E.P. (2003). Miðlun sögu á syningum: safna-og-syningaferð um Ísland 20022003. Saga, 41(2), 15-66.

23. A. Day \& K. Lunn, British Maritime Heritage: Carried Along by the Currents? IJHS, 94 (2003), 289- 305. doi:10.1080/1352725022000155045

24. F. McLean. Museums and the Representation of Identity. In B. Graham \& P. Howard (Eds.), The Ashgate Research Companion to Heritage and Identity (pp. 283-296). Hampshire: Ashgate (2008)

25. P. Leffler . Peopling the Portholes: National Identity and Maritime Museums in the U.S and U.K. The Public Historian, 26 (4), 23-48. Retrieved from http://www.jstor.org/stable/10.1525/tph.2004.26.4.23 (2004)

26. R.D. Hicks, What is a Maritime Museum? MMC, 19 2, 159-174. doi: 10.1080/09647770100401902 (2001)

27. L.Smith. Heritage, Gender and Identity. In B. Graham \& P. Howard (Eds.), The Ashgate Research Companion to Heritage and Identity (pp. 159- 178). Hampshire: Ashgate (2008)

28. B. Graham \& P. Howard. Introduction: Heritage and Identity. In B. Graham \& P. Howards (Eds.), The Ashgate Research Companion to Heritage and Identity (pp.1- 15). Hampshire: Ashgate (2008)

29. S. Hall (1996). Introduction: Who Needs 'Identity'? In S. Hall \& P. Du Gay (Eds.), Questions of cultural identity (pp.1- 17). London: Sage. Retrieved from http://blogs.unpad.ac.id/teddykw/files/2012/07/Stuart-Hall-Cultural-Identity.pdf

30. A. Pritchard \& N. J. Morgan, Culture, identity and tourism representation: marketing Cymru or Wales? TOURISM MANAGE., 22 ,167- 179. doi:10.1016/S0261-5177(00)00047-9 (2001) 
31. A. Magnusson, (n.d.). Icelandic fisheries: Social perspectives. Retrieved from http://www.hafro.is/ arnima/pdf/2006-itq-soc.pdf.

32. T.H. Tulinius. Vestfirðir: aflstöð íslenskrar sögu. In J. P. Pór \& V. Óskarsson (Eds.), Ársrit Sögufélags Ísfirðinga 2003 (pp. 17- 30). Ísafirði: Sögufélag Ísfirðinga (2003)

33. U. D. Skaptadóttir, Women Coping with Change in an Icelandic Fishing Community: A Case Study. WOMEN STUD INT FORUM, 23 ,3, 311-321. doi:10.1016/S0277-5395(00)00089-3 (2000)

34. Stefansson Arctic Institute. (2009). Fishernet Country Report Iceland. Akureyri, Iceland: n.a. Retrieved from http://www.fishernet.is/en/fishernet-country-reports

35. G.Gibbs . Analyzing Qualitative Data. London: SAGE Publications (2007)

36. E.Crooke. An Exploration of the Connections among Museums, Community and Heritage. In B. Graham \& P. Howard (Eds.), The Ashgate Research Companion to Heritage and Identity (pp. 415- 424). Hampshire: Ashgate (2008)

37. H. Kim \& T. Jamal, Touristic quest for existential authenticity, Ann. Tour. Res., 341 (2007), 181-201. doi:10.1016/j.annals.2006.07.009 (2007)

38. D.A. Fennell. Tourism Ethics Needs More than a Surface Approach. In T.V Singh (Ed.), Critical Debates in Tourism (pp. 188-190)(2012)

39. D.A. Fennell . Ethics and Tourism. In J. Tribe (Ed.), Philosophical Issues in Tourism (pp. 211226). Clevedon: Channel View Publications (2009)

40. D.A. Fennell. Tourism Ethics. Clevedon: Channel View Publications (2006)

41. J. Macbeth, Towards an ethics platform for tourism. Ann. Tour. Res., 324 (2005), 962-984. doi:10.1016/j.annals.2004.11.005 